\title{
Fusidate Sodium
}

National Cancer Institute

\section{Source}

National Cancer Institute. Fusidate Sodium. NCI Thesaurus. Code C65792.

A sodium salt form of fusidic acid, a bacteriostatic antibiotic derived from the fungus Fusidium coccineum and used as a topical medication to treat skin infections. 